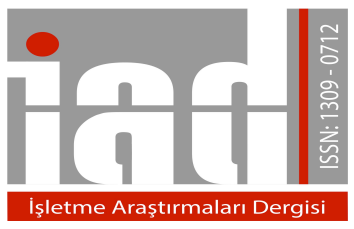

\author{
İşletme Araştırmaları Dergisi \\ Journal of Business Research-Turk \\ 10/4 (2018) 1100-1109
}

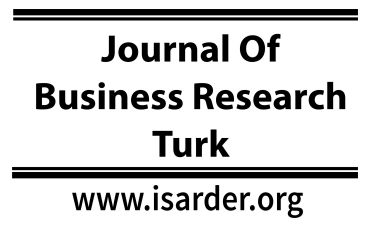

Research Article

\title{
Opinions of Business Representatives on International Tourism Fairs: A Qualitative Research Study
}

\author{
Oktay EMiR \\ Anadolu University \\ Open Education Faculty \\ Eskisehir, Turkey \\ orcid.org/0000-0002-7972-1980 \\ oktayemir@anadolu.edu.tr
}

\author{
Banu ZENCIR \\ Afyon Kocatepe University \\ Suhut Vocational High School \\ Afyonkarahisar, Turkey \\ orcid.org/0000-0001-7511-4932 \\ banuzincir26@hotmail.com
}

\begin{abstract}
The aim of this study is to reveal the opinions of tourism business associates about international tourism fairs. In this study, the unstructured interview technique was used as the data collection method. The research group included participants from businesses operating in the accommodation, airlines, catering, travel, and health tourism sectors who attended the international tourism exhibitions in Kiev/Ukraine, Minsk/Belarus, Tbilisi/Georgia and Seoul/South Korea in 2017. An interview on the subject was conducted with 32 participants and their opinions were recorded in a written form. According to the interview results, the exhibitors reported that taking part in international tourism fairs is generally useful for tourism businesses in terms of improving image, increasing knowledge of the international markets, better recognition of competitors, and being informed about the latest technology and managerial practices.
\end{abstract}

Keywords: international tourism fairs, tourism, qualitative research study

Received 10 October 2018; Received in revised from 20 December 2018; Accepted 25 December 2018

\section{Introduction}

Tourism is a rapidly growing business in the world and an important part of the service sector. Because of their economic and social benefits, countries care about tourism and make significant investments in order to get a share from this sector. Due to the characteristic nature of the tourism sector, marketing of tourism products and competition conditions are affected by many factors. Therefore, countries have to use marketing instruments effectively in order to attract tourists and maintain/expand existing tourism market shares. In addition, securing public support for the marketing activities is an important function. We can say that such marketing activities are not easy to perform due to the spread of tourism over a wide geographical area. Therefore,

\section{Suggested Citation:}

Emir, O., Zencir, B. (2018). Opinions of Business Representatives on International Tourism Fairs: A Qualitative Research Study, Journal of Business Research-Turk, 10 (4), 1100-1109. 
fairs, which offer important opportunities for the promotion and marketing of tourism values, attract business and leisure visitors to countries and destinations, enable the promotion of countries at international level, contribute to the intermingling of people and help develop domestic and international tourism. Popular tourism exhibitions also affect the destination image positively while bringing economic vitality and social benefits to the host place (Andenova, 2013).

Developments in tourism and other sectors and the emerging trends create a market environment where competition is intense. For this reason, it is not enough to produce quality goods and offer them to the market to achieve success in sales because, in the current conditions, consumers are offered various prices, qualities, and forms of the same goods and have the choice between different alternatives of the goods or services they need. (https://www.marmarafuar.com.tr/fuarlarin-onemi). As such, one of the ways in which countries introduce their exports, keep track of the tourism and technology opportunities in foreign countries, follow the developments and market opportunities in these countries and create an effective marketing platform is participating in international trade fairs (İstanbul Chamber of Commerce, 1977). Thus, well organized fairs are a global meeting point where a nation's production power, culture and aesthetics are showcased. National and international tourism fairs are emerging as a new type of industry especially in developed countries (Bahçetepe, 2009:11). Moreover, involving the participants in tourism fairs and festivals in the tourism development process, getting their opinions and suggestions, and exchanging views on the future development of tourism is very important in enabling them to influence the fair and festival organizers and thus feel a part of the tourism industry (Karakaş and Şengül, 2017). For this reason, exploring the opinions and perceptions of visitors attending such international fairs will provide a better and deeper understanding of their perspectives and make a significant contribution to the literature focusing on international fairs.

\section{Literature}

Fairs are the large exhibitions that are opened to showcase merchandise at certain times and in certain locations. Today, not only commercial goods but also services and entertainment are introduced and marketed at fairs. Therefore, fairs have key importance within the tourism sector, with a leading role in the service industry and major contribution to the national economy (Aymankuy, 2006). In addition, fairs are becoming increasingly important both to promote touristic destinations and to inform the visitors about the recent developments in tourism. Fairs serve two main purposes: they offer a platform for the marketing activities of the participating companies and help visitors both to establish good relations with the companies and to get the services they need (Çakıc1, 2017).

Fairs are one of the rare activities that can provide a face-to-face relationship between producers and consumers, buyers and sellers in global market conditions. At the same time, fairs are considered by tourism companies as a significant advertisement, sales and promotion tool in the marketing of their goods and services and have an important role in the marketing activities (Avan et al., 2016; Blythe, 1999; Hansen, 2004; Lin and Lin, 2013). Various criteria are mentioned for defining a fair as an international fair. However, at least $10 \%$ of the participants or at least $5 \%$ of the visitors are expected to be from foreign countries at international fairs. Considering the number 
of exhibitors and visitors coming from foreign countries and their ratio within the total, it can be defined whether the fair is an international fair for imports or exports (Andenova, 2013).

ITB Berlin Fair (adventure tourism, business tourism, e-tourism, cultural tourism, education and employment tourism, travel technology, youth travel \& economic accommodation), FITUR (International Tourism Fair, Madrid, Spain), MITT (International Travel \& Tourism Exhibition, Moscow) and EMITT (East Mediterranean International Tourism \& Travel Exhibition, Istanbul) can be given as the examples of international tourism fairs. We can say that such fairs contribute to tourism stakeholders, local people, tour operators, tourists, tourism entrepreneurs, and the private and public sector.

International ITB Berlin is the world's leading travel fair. At ITB Berlin, there are sessions on important topics for the sector such as "sustainable tourism," "digital developments" and "medical tourism." In 2018, 10,000 companies and organizations from 186 countries hosted about 170,000 people, including 110,000 commercial visitors (https://www.itbberlin.de). FITUR (International Tourism Trade Fair) is the global meeting point for tourism professionals and the leading trade fair for the Latin American buyer and export market. In the future projection of FITUR Tourism Fair, priority is given to market diversity, product diversity, seasonal diversity, urban tourism, cultural tourism and gastronomic tourism. In 2018, an international exhibition of 10,190 exhibitors, 140,120 commercial exhibitors and 110,860 visitors from 165 countries and regions participated in the international tourism fair (http://www.ifema.es/fitur ). MITT (Moscow International Travel \& Tourism Exhibition), the largest B2B (Business to Business) travel event of Russia and CIS, attracts representatives from the tourism sector from Russia and other parts of the world. In addition, it allows participants to increase their awareness of their goals, present their new programs and give them a real feel for the Russian travel market. It is one of the most prestigious fairgrounds in the world. Among the business lines of the visitors of MITT are; travel agencies, tour guides, corporate tours, hotels, accommodation and medical centers (http://www.mitt.ru). EMITT (East Mediterranean International Tourism \& Travel Exhibition, Istanbul) is a business platform that offers new business and collaboration opportunities to the sector as well as providing guidance to stakeholders, local people, tour operators, tourists, tourism entrepreneurs, the public sector and government, and all those interested in these fairs. The fair where participants have the opportunity to increase their business volume include country fairs, holiday destinations, summer tourism, winter tourism and outdoor tourism destinations, hotels and tourism centers, tour operators and agencies. EMITT tourism fair hosted 870 domestic and 195 foreign companies and 54.364 domestic and 3.379 foreign visitors participated in the fair. The most frequently attending countries are Macedonia, Bulgaria, Iran, Northern Cyprus, Germany, India, Greece, Azerbaijan, Iraq and Algeria. In 2018, a large majority of the visitors stated that they were satisfied with the fair and wanted to come again (www.emittistanbul.com).

The potential of tourism fairs given above attracts the attention of tourism researchers. There are many scientific articles and theses on exhibition activities in the tourism research literature, some of which are presented below. In his study on the results of the exhibitions and the expectations of visitors and exhibitors, Blythe (1999) emphasizes that the goals and objectives of the visitors and participants may be different 
but what matters is that the communication should be compatible with these goals and objectives. As the reasons for visiting the fairs, they were reported as being informed about the developments in the new products, taking the technical product information, keeping abreast of the current information about the legislations, and participating in the launch of the new products. Among the participants' intentions to visit fairs were staying in touch with developments, getting new ideas, following novelties, and observing the sector-specific innovations. Among their aims to have exhibitions, the exhibitors reported meeting new customers, improving the image of the company, interacting with the existing customers, and introducing the existing products. In their study on international trade fairs, Yüksel and Voola (2010) examined the motivations of the participants and the perception of the activities and challenges exhibited by the firms. As the most important promotional activities for the success of a country's international promotion, some goals were set such as having representative offices in the target markets, providing effective and efficient information, performing lobbying activities, having professional and trained fair staff, and having printed materials. Also, among the challenges of fairs follow-up of the contacts at the fair, performance evaluation of fairs, receiving effective government support, notification of the aims of the exhibitors were reported. The study conducted by Torun et al (2012) aimed to analyze the purposes of the participation of business organizations in the fairs, their legal positions and types, business operators' education and income levels, the importance of vocational education, the expectations of the operators from the fairs, and the differences between their aims and expectations. $61.8 \%$ of the participants stated that they participated in such fairs in order to promote their products, while $21.1 \%$ wanted to increase their market share by expanding their customer network. Esfidani et al. (2012) explored the role of tourism fairs in the development of sustainability in the tourism industry by outlining some advantages and disadvantages to be taken into account in tourism fair organization. However, tourism fairs can indisputably benefit from the right planning and supervision to reduce its disadvantages, which can contribute to the sustainable development of the tourism industry. In order to determine the purpose of the fair participation of enterprises operating in the sea tourism industry, Arl1 (2012) states that the most important trade fair participation objectives are "to introduce new goods/services," "to gain new customers and increase the profitability of the business," and, "to contact private customers and establish professional relationships." In another study, Rittichainuwat and Mair (2012) studied the participation motivation of visitors to fairs and festivals, in which the visitors to the consumer travel fairs stated that they had multiple motivations to participate. These motivations are the acquisition of sales information, interest in the subject, and media encouragement to visit them. Yoon et al. (2012) aimed to identify the ways in which trade fairs affect the participants and to develop strategies to enable the fair organizers to work more effectively to increase the positive results for the participants, and identified the stand-equipment level and the organizers' support activities as the two factors determining the quality of the fairs. Furthermore, they found that these two important factors were important for the exhibitors to participate in the fair organizations. Adenova (2013) found that the development of international tourism fairs had important contributions to increase the country image, tourism revenues and number of tourists. In another study, Baş (2014) examined the effects of international fairs on the participating companies and found that the exhibitors all agreed that participating in the international fairs offer many advantages for them. According to the 
results, such international fairs afford benefits such as promotion, improving brand image, increasing sales and making significant progress in internationalization in the globalized world. Jauhari and Munjal (2015) discuss the opportunities and challenges in tapping into the cultural and economic potential of fairs and festivals. This potential includes increasing the awareness of fairgrounds and tourism destinations, discovering the potentials for commercial and investment activities in the region, creating tourist attractions and new accommodation areas, and opportunities such as higher accessibility in the fair area. Avan et al.'s (2016) study reveal the event organization processes of the professional firms that host fair organizations and the problems they experience in these processes which involve some key concepts such as the potential and regional power of the sector and the city where the fair will be organized. They also list the problems that companies face in their organization hosting processes as follows: "The price policies of the organizer companies to obtain more added value at a lower cost result in insufficient publicity and marketing budget for the organization, the organizer firms cannot find adequately-qualified and capable staff to perform their marketing activities, and the incentives provided by the government to the organizers are insufficient." In another study, Şengel et al. (2017) researched the effects of congress and fair organizations on the tourism sector, and found that fairs can contribute both to the promotion of a certain country or destination, and to encouraging tourism. However, the fair participants also stated that they enjoyed finding opportunities for cooperation with the other companies. Cengiz and Yücel (2017) studied the attitudes of the participating companies towards the fairs and demonstrated the importance of fairs in marketing activities, revealing that the fairs had an important role for the marketing activities of the participating companies. Furthermore, they also determined that fairs offer significant advantages, particularly in promoting the available products and in carrying out market analysis for the new products. Another finding they reported is that participation in international fairs is crucial, and the budget allocated to fair participation needs to be increased.

\section{The Aim and Methodology}

The aim of this research is to reveal the participant views of international tourism fairs by drawing on expert opinions. Interview method was used as the data collection tool. The interview process is described as asking people, whose views are needed, the questions that were previously prepared according to the research purpose (Ural and Kilıç, 2018). The interview provides free exchange of information between the interviewer and the interviewee to reveal the opinion of the source person (Balc1, 2001). The "unstructured interview technique" was employed in this study. The data to be obtained by such a technique are expected to yield richer information than by asking direct and structured questions to individuals resulting in associated responses (Ekiz, 2009). The universe of research comprises the participants attending the International tourism exhibitions held in Kiev/Ukraine, Minsk/Belarus, Tbilisi/Georgia, and Seoul/South Korea in 2017 from the accommodation, airlines, catering, travel and health tourism business lines. A total of 32 interviewees who are professionals from the tourism sector including operators in the aforementioned subsectors were interviewed and their opinions were recorded in writing. 


\section{Results}

The data derived from the interviews conducted with 32 participants were analyzed through qualitative content analysis and the major findings regarding the views of the participants are presented in the following table.

Table 1. Major findings of the qualitative data

- Being worthwhile and advantageous

- Learning about foreign competitors

- Gaining more knowledge about the market

- Fairs as communication channels with the outside world

- Improving the company image

- Cooperation with foreign companies

- Transfer of technology and managerial practices

Participants generally agree that it is worthwhile and advantageous to participate in international tourism fairs. They underline the importance of participating in trade fairs, especially with the aim of learning more about the foreign competitors. They stated they had the chance to compare themselves with other firms operating in the same line of business, and gained more knowledge about their product ranges and marketing methods and techniques. They emphasized that the fairs served as a school for renewing themselves and as an important communication channel for opening to the outside world. They also reported that it obviously costs to participate in such fair organizations, but it is useful to participate in these organizations to improve company recognition. In addition, the view that participating in international fairs offers advantages to improve the company image is shared by all the participants. On the other hand, participating in such organizations provides advantages to the company both in domestic and foreign markets. Just turning to a limited market increases the risks. In this respect, focusing on different markets also reduces the impact of potential risks. Participation in such fairs also offers opportunities for the development of cooperation with foreign companies or even for new partnerships. Firms also reported having combined their human and material strengths to make joint efforts, thus reaching out to remote areas, thus creating easier and less costly business opportunities. Cengiz and Yücel (2017) found that fairs provided significant advantages especially in the promotion of existing products and in the conduct of market analysis for new products. However, they expressed the need to participate in international fairs and to improve the budget allocated to fairs. On the other hand, the transfer of technology and managerial practices are some of the common advantages reported by the participants. Moreover, they reported that travel trends of individuals change constantly, and it is not easy to follow these changes and develop appropriate tourism products, and thus, it is an advantage for companies to create new markets both vertically and horizontally in different destinations. They emphasized that fair participation by the firms operating in the tourism sector is important for the presentation of physical evidence. In other words, they want to address any possible questions on their customers' minds when choosing their tourism products and they want to resolve such hesitations. In this respect, the 
participants stated that every detail, from the selection of the fairgrounds to the visual and printed materials to be used, should be meticulously planned. In addition, they stressed that the staff serving in the fair organization should have adequate foreign language skills and have satisfactory knowledge about the products of the competitor companies. Participants also think that tourism fairs play a very important educational role as a tool that provides information flow between market and firms. These companies further agree that tourism fairs are effective in helping companies to promote their products and in their branding processes through better recognition in wider circles. In their study on international trade fairs, Yüksel and Voola (2010) have identified some major objectives regarding international promotion success, which include having a sales office agent in the target markets, providing effective and efficient information, implementing lobbying activities, having professional and trained fair staff, and having printed promotional materials. In addition, among the challenges of fairs, follow-up of the contacts at the fair, performance evaluation of the fairs, receiving effective government support, and notification of the exhibitors' aims were reported. Participants acknowledge the importance of tourism fairs in the future plans of their organizations. They stated that they need information to monitor changes in tourism trends and make predictions, therefore, they think that fairs help better plan the future, however small that help might be.

\section{Conclusion and Suggestions}

Tourism fairs have national and international importance. In this regard, it is important for tourism business organizations to participate in tourism fairs to follow the developments in the tourism market and to promote themselves. Evidently, for businesses that are not sufficiently institutionalized and have not reached a certain economic size, it is not possible to participate in such activities due to the financial burden. A further point is the level of awareness that tourism businesses have of the importance of this issue. Increasing competition and the number of enterprises in similar business lines makes it difficult for companies to maintain their presence in the market. However, the enterprises that adapt to these changing and developing conditions achieve success in maintaining their assets. The participants whose opinions were referred to within the scope of this research all agree that tourism fairs make a significant contribution to promotion. Since the high cost of participation in these organizations and the payment of stand fees in foreign currency restrict the ability of small and medium-sized enterprises to promote their products in these markets, the participants stated that the steps to be taken by the state to subsidize such organizations would increase their success. Furthermore, the participants stated that attendance to such fair organizations not only by tourism enterprises, but also by the artists, authors and representatives of civil society organizations that are the cultural values of the countries participating in such organizations would be more effective on the target audience. They also stated that they appreciate the great support given to them during their participation in tourism fairs by the "culture and tourism consultancies," which laudably represent Turkey in the international arena.

Although the current study presents a deeper understanding of the participants' perspectives on international fairs, it has some limitations. First of all, the findings are limited to the views of the participants of the study who are representatives from visitors. Besides, the data collection tools include semi structured interviews and benefiting from just one data collection tool remains as another limitations. However, in 
spite of such limitations, the study provides a rich amount of data on visitors opinions and perspectives. Based on this, it is concluded that further studies focusing on different stakeholders such as coordinators or administrators to get various points of views by employing multiple forms of data collection tools would be the right way to study on this topic and provide a richer understanding of international fairs.

On the other hand, the results of other research on tourism fairs are given in the literature section of this study. In other studies related to the subject, Blythe (1999), Torun et al. (2012), and Arl1 (2012) stated that the fair organizations are a good platform to meet with new customers, to improve the company image, to interact with the existing customers, and to present existing products. In another study, Chen and Mo (2012) examined the service quality of the fair organizations in six dimensions as stand management, recording, content, stand and exhibition attractiveness, stand layout, and function. They concluded that the most important dimension of the service was the "exhibition content." In another study, based on interviews with international tourism fair participats, Anenova (2013) found that the development of international tourism fairs will improve the country image and the tourism revenues of the country as well as increasing the number of tourists.

The limitations of this study can be expressed as follows: This study reflects the expert opinions only of the tourism fairs organized for health, food and beverage and travel / accommodation purposes. In this respect, it is difficult to generalize the opinions of the experts in tourism fairs. In addition, a limited number of people were interviewed due to time and cost factors. Therefore, it would be more appropriate to make generalizations on the basis of opinions obtained from a higher number of participants and experts about more diverse tourism fairs.

\section{Acknowledgements}

We would like to express our gratitude to Project Department of Anadolu University and the staff for their support and contribution (Project No: 1605E264). 


\section{References}

Andenova, A. 2013. Uluslararası Turizm Fuarlarının Kazakistan Turizmine Etkileri. (Effects of International Tourism Fairs on Kazakhstan Tourism). Published Master's Thesis, Istanbul University, Institute of Social Sciences, Department of Tourism Management, İstanbul. (in Turkish).

Arl1, E. 2012. Deniz Turizm Endüstrisinde Faaliyet Gösteren İşletmelerin Fuarlara Katılım Amaçlarının.Firma Performansı ile İlişkisi. (The Relationship of the Fair Participation Aims of Firms Operating in the Sea Tourism Industry with Firm Performance). Seyahat ve Otel Işletmeciliği Dergisi 9(3), pp. 25-37.

Avan, A., Zorlu, Ö. ve Baytok, A. 2016. Fuar Organizatörlerinin Bakış Açısıyla Fuar Organizasyonlarının Belirleyicileri ve Yaşanan Sorunlar. (The Determinants of Fair Organizations from the Perspective of Fair Organizers and Problems). Akademik Sosyal Araştırmalar Dergisi 4 (37), pp.216-230.

Aymankuy, Y. 2013. Kongre Turizmi ve Fuar Organizasyonlar1 3. Bask1. (Congress Tourism and Fair Organizations 3rd Edition). Detay Yayıncılık, Ankara.

Bahçetepe, T. 2009. Ekonomik ve Kültürel Gelişimin Vazgeçilmez Aracı: Fuarlara Katılım Rehberi. (An Indispensable Tool for Economic and Cultural Development: A Guide to Participation in Fairs. İstanbul Ticaret Odasi: İstanbul.

Balcı, A. 2001. Sosyal Bilimlerde Araştırma Yöntem, Teknik ve ilkeler, 3. Baskı, (Research Methods, Techniques and Principles in Social Sciences, 3rd Edition) Pegem A Yayınları: Ankara.

Baş, A. 2014. Fuarların Katılımeı İşletmelere Etkileri Marmomacc Taş Tasarımı ve Teknolojisi Fuarı Katılımcı İşletmeleri Üzerine Bir Araştırma. (The Effects of Fairs on Participating Firms: A Study on Marmomacc Stone Design and Technology Exhibition Participants). Published Master's Thesis, Anadolu University Institute of Social Sciences, Department of Business Administration, Eskişehir. (in Turkish).

Blythe,.J. 1999. Visitor and Exhibitor Expectations and Outcomes at Trade Exhibition. Marketing Intelligence \& Planning 17(2), pp. 100-110

Çakıcı, Ç. A. 2017. Toplantı Yönetimi. (Meeting Management). Detay Yayıncılık:Ankara

Cengiz, F. ve Yücel, E. 2017. Pazarlama Faaliyetleri İçin Fuarların Önemi. (Importance of Fairs for Marketing Activities). Journal of Travel and Tourism Research 12, $72-80$.

Chen, F.H. and Mo, H.M. (2012). "Attendees' Perspectives on the Service Quality of an Exhibition Organizer: A Case Study of a Tourism Exhibition", Tourism Management Perspectives, 1(1), 28-33.

Ekiz, D. 2009. Bilimsel Araştırma Yöntemleri, Geliştirilmiş 2. Bask1. (Scientific Research Methods, Improved 2nd Edition.) An1 Yayınc1lık: Ankara.

Esfidani, M. R., Vahabzadeh, M. and Tajalli, M. 2012. Examining the Role of Tourism Exhibition in Sustainable Development of Tourism Industry. International Journal of Business and Management Studies, 4 (2), 113-120. 
Hansen, K. 2004. Measuring Performance at Trade Shows Scale Development and Validation. Journal of Business Research 57(1), pp. 1-13.

http://emittistanbul.com/EMITT/media/ITEGroup/Pdf/Emitt-18-PSR.pdf

(E.T:14.11.2018).

http://www.ifema.es/fitur_06/Informacion_general/Presentacion/index.htm. (E.T:03.11.2018).

http://www.mitt.ru/en-GB/about/stat.aspx (E.T:07.08.2018).

https://www.itbberlin.de/en/Press/PressReleases/News_52689.html?referrer=/en/Press/P ressReleases/ (E.T:03.11.2018).

https://www.marmarafuar.com.tr/fuarlarin-onemi/.(.E.T:03.11.2018).

Jauhari, V. and Munjal,S. 2015. Fairs and Festivals in India: The Cultural and Economic Potential. Article in Worldwide Hospitality and Tourism Themes 7(4):324-330

Karakaş, A. ve Şengül, H.İ. 2017. Yerel Halkın Turizm Faaliyetlerine Yönelik Tutumlar1 (Attitudes of Local People towards Tourism Activities). Bartın Üniversitesi İ.I.B.F. Dergisi 8(15), pp. 183-202.

Lin, C. and Lin, C. 2013, Exhibitor Perspective of Exhibition Service Quality. Journal of Convention \& Event Management 14(4), 293-308.

Rittichainuwat, B. and Mair, J. 2012. Visitor Attendance Motivations at Consumer Travel Exhibitions. Tourism Management 33(5), 1236-1244.

Şengel, Ü., Zengin, B., Şengel, T. ve Işkin, M. 2017. Kongre ve Fuar Organizasyonlarının Turizm Sektörüne Etkileri: Emitt Örneği. (Effects of Congress and Fair Organizations on the Tourism Sector: Emitt Example). Turizm ve Araştırma Dergisi 7(1), pp. 4-20.

Torun, E., Çelik, A. ve Bobat, A. 2012. Pazarlamada Fuarların Rolü Ve Önemi (Yalova Süs Bitkileri İhtisas Fuarı Örneği). (The Role and Importance of Fairs in Marketing (Yalova Ornamental Plants Specialization Fair). KSÜ Doğa Bil. Derg., 15(2), pp.11-21.

Uluslararası Fuarlar ve Türkiye 1977. İstanbul Chamber of Commerce publications.

Ural, A. ve Kılıç, İ. 2018. Bilimsel Araştırma Süreci ve SPSS İle Veri Analizi, 5. Bask1. (Scientific Research Process and Data Analysis with SPSS, 5th Edition.) Detay Yayıncilık: Ankara.

Yoon, K., Lim, S. and Park, N. 2012. Impact of Pavilion Quality on Exhibitor Performance at an International Trade Exhibition. Procedia Social and Behavioral Sciences 40, 681-688.

Yüksel, Ü. and Voola, R. 2010. Travel trade shows: Exploratory study of exhibitors' perceptions, Journal of Business \& Industrial Marketing 25(4), pp. 293-300. 